\title{
Decolonising Penal Substitution Theory of Atonement: A Theology of Forgiving-Love in the Church of Christ in Nations (COCIN) in the Violent Context of Jos, Nigeria
}

\author{
Yusuf J. Luxman \\ ORCID iD:
}

\section{Chammah J. Kaunda \\ ORCID iD: https://orcid.org/0000-0001-6879-6330}

\section{Roderick R. Hewitt}

ORCID iD: https://orcid.org/0000-0003-1226-4671

\section{Abstract}

This article argues that the retributive element embedded within the understanding of the Church of Christ in Nations (COCIN) of the Penal Substitution Theory (PST) has the potential to promote indifference to people of other faiths. The article employs Inculturation as the analytical tool to decolonise the PST, with reference to the Pyem people's philosophy of forgiving-love in a context plagued by religious violence. The primary data was created through a qualitative research method and thematic analysis of relevant information. Qualitative, open-ended questions that allowed participants to contribute freely based on their experiences, were asked; also, focus group interviews were conducted among the Pyem people in Jos, Nigeria. The key findings that emerged show that the Pyem religio-cultural experience is embedded in its religio-cultural notion of Ngwakin Darsai Daal (the male that reconciles), which presupposes humanity as the backdrop of forgiving-love. The article concludes that the conversation between the Gospel and culture is aimed at stimulating practical forgiving-loving.

Keywords: Decolonisation, penal substitution theory, Church of Christ in Nations, Nigeria, forgiving-love 


\section{Introduction}

This article relates to the Pyem people's notion of ngwakin darsai daal (male goat of forgiving-loving), which represents an advanced symbolic expression of a love for humanity, and which is embedded in their concept of forgivinglove as a resource for conflict resolution. This notion is rooted in the Pyem adage, Do ta chalai ram (humanness comes first before any other thing). The concept of forgiving-love is expressed in its present continuous tense; it is a practical lifestyle of unconditional love clothed in a consistent ethic of forgiveness and reconciliation, rooted in African accumulative wisdom through interaction with reality. It is poignantly expressed in a proverb of the Bemba people of Zambia: Imitiilipamotailbulakushenkana (trees near to one another do not stop rubbing each other and do not stop appreciating, forgiving and loving each other). This honest and authentic interpretation of reality is significant in the context of religious pluralism, which tends to ignite violent religious conflicts. The ngwakin darsai daal is used as a traditional idiom to decolonise the penal substitution theory (PST) of the doctrine of atonement as understood and practiced by Church of Christ in Nations (COCIN) in Jos, Nigeria ${ }^{1}$.

The PST, as practiced by the COCIN, is based on colonial missionary and judicial understanding, which presupposes that Christ, through his death, bore the punishment that fallen humanity were to suffer for. The colonial missionary notion of the PST of atonement is entrenched in a retributive theology that was uncritically embraced by the COCIN. Scholars, such as Ben Pugh (2015), and Anthony Bartlett (2001), have called for a shift from the Eurocentric and judicial understanding of PST of atonement, to appreciating

${ }^{1}$ COCIN is an evangelical mission founded under the auspices of the Sudan United Mission, whose Protestant European missionaries came from Germany, through Sudan, to Nigeria, with the objective of engaging in mission work in the sub-Saharan region of Africa. Originally, the Church was named using the indigenous language Ekklessiyar Kristi a Sudan (EKAS) (Rengshwat 2012:88). The name of the Church was first changed to Ikklisiyar Kristi a Nigeria (EKAN), after it was renamed Church of Christ in Nigeria (COCIN), and then Church of Christ in Nations (Goshit, Lere, Tang'an, Longkat \& Gutip et al. 2013:2-6). COCIN, as described in this article, serves as the church where the penal substitution theory is understood and practiced within the violent context of Jos. 
the atoning work of Christ as representation of love and forgiveness between conflicted communities. The forgoing raises the following key questions for investigation: To what extent has the COCIN's understanding and practice of PST contributed to much-needed peace in Jos? How was this doctrine transmitted into the missional thrust of COCIN? To what extent does the understanding and practice of the PST of atonement within the COCIN demonstrate forgiving-love? How can the idiom, ngwakin darsai daal, be utilized as resource to decolonise PST within the COCIN?

\section{On Decolonial Methodology}

Decoloniality refers to the struggle to destabilise universalisation of colonialmissionary-dominant missiological thought. Decoloniality underlines that the historical colonial missionary theology of PST of atonement continues to inform the COCIN's theological imagination in contemporary Nigeria. Colonial missionary theological thought was informed by the idea of civilizing the so-called dark continent of Africa through evangelism - not merely evangelism of the people, but a comprehensive process of cultural alienation and redesign of the African at its fundamental level, to become a people that mimic and reflect European Christian interpretation and understanding of religion. This process is classified as Coloniality of Christian faith and religious imaginations. A Christian worldview, 'entangled, woven, trapped in the colonial matrix of power' (Mignolo 2007:155) emerged, based on missionary theological thought and a foundation for organising human relationships and interactions with the world. Coloniality, as long-standing patterns of Christian imaginations, beliefs and practices, which emerged as a result of colonial missionary evangelisation of Africa, continues to define Christian expressions of African culture, social relations, and theological production, long after the end of the direct colonial missionary enterprise (Kaunda 2015; 2016).

This article utilises the concept of decoloniality as an analytical tool to decolonise the PST in conversation with African religio-cultural experience, as the medium of expression, in an attempt to divorce the alleged retributive tendencies from the PST of atonement as practiced by the COCIN, and to present an understanding of Christ's substitutionary atonement that adequately expresses forgiving-love, in the violent context of Jos. The fluid nature of Decolonial approaches makes it easy to adapt them to cultural philosophies, 
such as ngwakin darsai daal. This African religio-cultural practice, which is found among the Pyem ethnic group in Jos, Nigeria, is utilised by the Pyem as a Decolonial idiom within which PST could find a more locally embedded meaning and application. This notion stems from the Pyem people's understanding of forgiving-love in the context of violent conflict between two warring communities.

As part of a qualitative Decolonial research method, group discussions were conducted with Pyem indigenous people. Participants were selected purposively, based on experiences of participants and whether the information they could provide would benefit the subject under consideration. The method allowed participants to contribute freely, based on their understanding of the traditional notion of forgiving-love, and how it can be applied in response to conflict between conflicting parties. The strategy for recruiting research participants was heterogeneous (not of the same kind or nature).

A group of nine male and female elders who were well-versed in indigenous forms of knowledge were selected from the Pyem ethnic group; they may or may not have been members of the COCIN. Those who were COCIN members expressed themselves based on their understanding and practice of PST, and from their cultural experiences within the Pyem ethnic group. Participants suggested how their religio-cultural experiences can serve as resource for reconceptualising the doctrine under consideration for peace building in Jos.

\section{Coloniality of Missions}

Eurocentrism is a system of thought that developed within the cultural and social sphere of Europe, and that seeks to undermine other systems of thought by taking western European values and culture as the universal standard through which humanity can be ascertained (Araujo \& Maeso 2017). A Eurocentric system of thought postures ethnic, cultural and religious superiority over African people and their life worlds (Serequeberhan 1997). This assumption has been expressed in different forms by traditional Eurocentric epistemologies, for example, Emmanuel Kant states that, 'The Negroes in Africa have by nature no feeling that rises above the trifling' (1960:110-111). Similarly, Georg W.F. Hegel (Hegel 2001:93) states that,

The Negro as already observed exhibits the natural man in his com- 
letely wild and untamed state. We would lay aside all thought of reverence and morality-all that we call feeling if we would rightly comprehend him there is nothing harmonious with humanity to be found in this type of character.

European-centred ontology applied to non-European epistemology connotes supremacy and bias against a system of thought, especially that of Africa, with its pluri-religious context. The Eurocentrism-characterised COCIN missionary notion of PST of atonement was imposed on the Pyem people in Nigeria. The approach employed by the European missionaries in the process of planting the COCIN within the local context is explained by the pioneering missionary, Karl Kumm².

We lay aside the newspaper and ask what does this mean this seems in the Central Sudan? Among semi-Muslim, semi heathen, wholly nonChristian people. What does this cheering for the greatest, darkest, and most suffering of all and ruled by Islam, Islam can rule no longer. The land of God is taking its power away (1907:15).

One of the main aims of the COCIN missionaries was to halt the advance of Islam across West Africa. Initial efforts focused on the Benue region of Nigeria. As a result, the Church and its mission has functioned in a perpetual 'crusading state' against those in society that follow other belief systems. This 'devaluation of the other' in the understanding of the doctrine has contributed to weak social cohesion in Jos, and this has led to a disposition characterised by an embrace of physical force as a way of expressing power and control over others (Boer 2014:16-17). COCIN's traditional teachings of PST and the doctrine of the atonement has promoted religious superiority, and a belief that the Christian faith has the only authentic claim to truth, namely, that God sacrificially offered the life of Jesus, his only son, as the means to overcome the consequences of sin in the world (Boer 2014:16). Inculcating this understanding in the clergy and members during leadership and discipleship formation may breed contempt and retaliatory responses to people of other faiths.

${ }^{2}$ Dr. Hermann Karl Wilhelm Kumm was a German missionary who started the Sudan United Mission (SUM), mission agency that sent missionaries to Africa and also worldwide through which COCIN was established. 
Furthermore, PST was conceptualised within a context characterised by the classical European judicial system of justice (Green \& Baker 2000:169). Therefore, the COCIN adopted PST into its missional identity within the framework of Eurocentrism. The approach was culturally insensitive to the religious diversity and social plurality of the local context. In view of this retaliatory connotation, this article argues that the PST of the doctrine of atonement, which is supposed to facilitate love, forgiveness and peaceful coexistence within the community where it functions, is likely to become a promoter of intolerance and violence within a context that is already characterized by religious violence (Pugh 2015:154). The classical Eurocentric judicial system of thought during the transmission of the PST into the missional identity of the COCIN was expressed when recipients of the Gospel were asked to take oaths as a condition for allegiance to the new religion. Seth Nden (2013:56) quotes that,

We the undersigned having been baptized in conformity with our faith in Langtang, we solemnly covenant with each other to live together in the love of the Lord Jesus Christ to strengthen and build each other up in the faith.

According to Nden, about 18converts signed a document to demonstrate their acceptance and that they would obey the rules of the new religion, to which they were now converted. It can be argued that the missionaries acted according to their European religio-cultural and judicial system of thought (Bate 2000:27). It can also be argued that the symbolic representation of PST in the COCIN appears to facilitate the use of violence, because the doctrine implies that every wrong is punishable by law (Lenman \& Parker 1079:140). Scholars point out that reformers, such as John Calvin, placed great emphasis on God as being avenging judge, who would prevent the law from being violated by those who have committed wrongs (Pugh 2015:67-82). Lenman and Parker (1993:140), in their evaluation of criminal law in early modern Europe, argue that Calvin the reformer, who was a lawyer, oversaw several executions of persons accused of breaking the law, and this was attributed to his regressive interpretation of the PST. In order to decolonise PST of atonement, there is a need to converse with local idioms that provide a better expression of the atoning work of Christ that represents love and forgiveness. The decolonisation of PST is carried out in conversation with the African 
notion of ngwakin darsai daal, which adopts forgiving-love as its praxis, to reconcile conflicting communities.

\section{The Challenge of a Christian Response to Religious Violence}

Scholars highlight that Christians' responses to violence against people of other faiths (religions) seems to exacerbate religious conflicts in Nigeria (Ezigbo 2018). The theological rhetoric within the public square reveals that the retaliatory responses of Christians to the religious violence may be attributed to the triumphalist expressions of the Christian claim to truth, as the only true religion, the quest to fight for their own rights, and the fear of religious hegemony by Islam and Muslim, as experienced as attempts to Islamise Nigeria (Ezigbo 2018:238). Christianity is the dominant religion in Plateau State, particularly in Jos. Among various Christian denominations, the COCIN is the 'oldest and perhaps largest Christian denomination in Plateau State with branches in almost all the states of Nigeria' (Wika 2014:3). However, the COCIN's understanding and practice of PST has not adapted to engaging the phenomenon of religious violence through the traditional notion of forgiving-loving.

Bishop Kaigama of the Roman Catholic Church of Jos, who was one of the inter-religious committee members for peacebuilding between 2001 to 2010 , argues that religious leaders should place more emphasis on practical works of forgiving-love that improve the lives of people, than on limiting their ministry to simply preaching and teaching (Krause 2010:56). The Bishop's comment suggests that the ecclesial community has embraced a schizophrenic missional identity, in which preaching the good news has failed to conform with the way the mission of Jesus's love and forgiveness embraces everyone, irrespective of their affiliation (Kaunda 2015. This failure was especially visible in the Christian response to the threats of religious violence in Jos. The COCIN's teachings on the finished work of Christ, which embodies love and forgiveness, seem to have been replaced by intolerance and violence against people of other faiths (Ezigbo 2018:238). Scholars have observed that the involvement of Christians and Muslims in reprisal attacks has resulted in mosques and churches being burned (Ezigbo 2018; Pokol 2015; Uzodike \&Obaje 2013). Writing on the response of the COCIN to religious violence, scholars attribute the COCIN's retaliatory attitude to a legacy of missionary intolerance and triumphalist proclamations of the Christian message against 
Islam (Eden 2013; Pokol 2015).

Although the superlative statements in the COCIN missionary heritage were meant to motivate people to give attention to the need of reaching North Central Nigeria with the Christian message, its missional posture and strategy advocated competition and judgment against Muslims (Pokol 2015). As Ezigbo (2018) observes, missionary intolerance against Islam could be easily be misconstrued by fundamentalists as a means of sanctioning the use of violence against the followers of Islam and other religions. In the COCINdominated communities of Dutse Uku in Jos, a group of Christians was seen chanting, 'come out and fight for Jesus' before the violence started (Higazi 2011:24). To them, fighting Muslims was equivalent to fighting for Jesus.

Responses of COCIN members to violence against people of other faiths in Jos suggests that their understanding and practice of the finished work of Christ is restricted to meeting their inner ecclesial needs, and does not extend to offering love and forgiveness to those considered to be enemies (Pokol 2015). This notion of PST of the atonement, seems to perpetuate an intolerant legacy of missionary evangelistic heritage, which is rooted in combating the scourge of Islam and the slave trade in Northern Nigeria (Nden 2013; Pokol 2015). This doctrine was transported and transmitted into the missional identity of the COCIN, to perpetuate a retaliation discourse against those perceived to oppose the Christian message of salvation in Christ. The retributive and retaliatory features of PST, as practiced by the COCIN, seem to pose a serious challenge to its missional thrust in Jos. Due to the violent implications of the doctrine, the reciprocity of love and forgiveness that the PST should embody may not be realised by the Church's mission, because of religious bigotry and violent attacks by people of other faiths (religions) in Jos (Taylor 2006: 2). It is in the light of this assumption that this article calls for an afro-centric religiocultural and contextual perspective to decolonise PST. The promotion of this shift is based on ongoing discourse, which holds that, within the African worldview, there are viable religio-cultural experiences that can serve as mediums of expression, and which have the capacity to express love and forgiveness in the context of violence.

\section{Reclaiming the Pyem Decolonial Motif}

Forgiving-love within the African system of thought is rooted in its worldview that the value and dignity of a human is derived from other human beings, and 
the value and dignity of all humanity is derived from an individual human being. Both Christians and Muslims are embedded in the Pyem worldview, which prioritises humanness of all above anything else. There is hardly any practice of Islam or Christianity that takes a complete break from an African cultural heritage that is embedded in humanness as the common essence (Pokol $\&$ Kaunda 2015). This ideological principle is embedded in the way Africans understand God in relation to humanity and the community (Bujo 2015). The concept of humanness unifies African people's thoughts and ideas about life, thereby maintaining harmonious relationship through forgiving-love in the situation of violent conflict (Pokol \& Kaunda 2015). Bishop Desmond Tutu affirms the relevance of African epistemology for conflict resolution through the adage, 'A person belongs to a greater whole and is diminished when others are humiliated or diminished when others are tortured and oppressed' (1999:27). Thus, in belonging to a greater whole in the context of religious conflict and animosity, the implication of the African worldview connotes an idea of forgiving-love, irrespective of who is seen as the winner or vanquished between conflicting communities. Within the Pyem system of thought, ngwakin darsai daal is a symbolic cultural practice that enshrines forgivinglove as the basis for overcoming violence, and restoring loving relationships and humanness among conflicted people. Religious violence robs both Christians and Muslims of their humanity and humanness (Kaunda, Luxman \& Hewitt 2018).

The Pyem ethnic group is popularly known for its loving hospitality and inclusivity. They believe and affirm the humanity of all, despite others' race, colour, and religion or gender (Kaunda et al. 2018). This is evident in the way the Pyem have accommodated many other ethnic groups within Plateau State of Nigeria, which used to be exclusively theirs (Temple 1965:120). Machunga (1964) notes that, due to their hospitality, tolerance and love, the Pyem welcomed and received Western missionaries, especially those of the SUM, and adherents of Islam from the far northern part of Nigeria.

The belief and practice of ngwakin darsai daal could be attributed to the Pyem's ontology, which is centred on promotion and appreciation of humanity of all before anything else. In the case of conflict, Pyem people are quick to call for conflict resolution, in which middle persons, in consultation with Bwalbwang, the chief priest and his subordinates, have the responsibility toinitiate dialogue between two warring communities (Bida 16 November 2017). A meeting of the communities is organised at the boundary, where each 
community presents a male goat through its representative. After an instruction by Bwalbwang, whose words were believed to be empowered by the Supreme Being, through the ancestors, the two representatives, in the presence of the communities, exchanged goats. Samuel Kallamu stated that,

Bisagawannanaladan, kabilubiyu da sun yifada da juna, kowannensuzaikawobunsurudaya, saannanzasumusanya a wurinhaduwa, [Based on the Pyem cultural practice, after each of the conflicting community presents a male goat, it should be exchanged at the meeting place by the warring communities] (Kallamu 16 November 2017).

The use of the male goat is based on the understanding that it is a notorious animal that is known for its predatory nature. The male goat represents the ugly nature of human beings, which causes conflict. This evil nature is believed to cause destruction of lives and property. The goat also represents violence against women and children during a fight (Tafida, 16 November 2017). The male goat is known for its ugly forehead, in particular. AuduWani (16 November 2017).stated that, Nyen sai Ngwakin Darsai Daala, which can be translated as, 'see his or her forehead as the male goat that stops fighting'. Among the Pyem people, children, women, men and slaves who are disobedient and arrogant in respect to life in the Pyem community are, therefore, described as goats (Moko, 16 November 2017). According to Mary Sokale and Lori Tafida (16 November 2017), the sacrifice and eating of the male goat implies that the anger, animosity and grievances that each member nurses against the other is forgiven through unconditional love that emanates from the understanding that all are human, irrespective of differences.

Within this system of thought, the beauty and essence of the community are human beings, and the beauty and essence of human beings in the community is an individual person. A Nigerian proverb says, 'A single tree cannot make a forest'. However, it is equally true that no forest can be made without individual trees. This assumption is expanded further by the Igbo people of Nigeria, who consider forgiving-love within the Igbo religio-cultural experience to be embedded in the understanding that humanity lives in a chaotic world and that every member of the community is duty-bound to tame the scourge of violence and other life-denying threats within the larger community. Community members participate in negotiations, and dialogue is initiated purposely to reconcile conflicting individuals and communities. In 
this practice, love and forgiveness is expressed by religious and social interactions between conflicting parties in the aftermath of violence (Njoku 2009: 94). Thomas Aquinas argued that eminiscedon is humanness, which can be seen as the backdrop for peaceful co-existence, and explained that a human person is naturally inclined to harmony, irrespective of affiliation, and that there is a natural disposition for forgiveness in the heart of every human being. Although Thomas Aquinas's supposition emanates from a Eurocentric background, its relevance forgiving-love as expressed within distinctive African moral ethics cannot be underestimated (Bujo 2015:86).

Forgiving-love, as expressed in the African religio-cultural experience, has the potential to create a space to explore it as a medium through which the love and forgiveness acts of the PST can be expressed by the COCIN. Applying the Pyem notion of ngwakin darsai daal as an alternative, symbolic, African medium for understanding PST appears to have the potential to promote a more humanity-prioritising approach to violence in Jos, instead of the approach of religious and political prioritising.

\section{Towards a Theology of Forgiving-Loving}

The Pyem notion of ngwakin darsai daal, used as aliens to decolonise the COCIN's understanding and practice of PST, focuses on forgiving-love as the basic tenet of the atoning work of Christ. This reconceptualization is essentially aimed at developing a Christian culture of forgiving-love within the COCIN's missional thrust, which represents Christ's model of love and forgiveness in the context of religious violence in Jos. Although there could be different understandings and interpretations of PST, based on the context being theologised (Ukpong 2000:17), the basic tenets that constitute the doctrine under consideration cannot be negated. Wynne Grudem (1994:567) holds that love is the ultimate cause of the substitutionary work of Christ. The kind of love expressed in the atoning work of Christ is the transforming instrument for forgiveness and reconciliation (Buthelli 2015:782-783).Vanhoozer (2004:397 - 399) argues that the substitutionary work of Christ is rooted in God's unconditional forgiving-love, which cannot be explained by any human word. Although these scholars speak from different perspectives and contexts, love is projected as the main element of the atoning work of Christ. Taking root from John 3:16 and its projection of love, Jesus reaffirms that love is the greatest of all commandments (Matthew 22:39), and is a clarion call to his 
disciples to reciprocate love, not only to those who love them, but also to their enemies (Matthew 5:44).

The second key element of PST is forgiveness. Within the dialogical disposition of the atoning work of Christ, forgiveness is understood as an element of PST that should be exhibited by Christians in the context of religious violence, such that as in Jos. As argued above, the retributive inclination of the COCIN's PST doctrine relegates forgiveness, which is a critical part of the atoning sacrifice of Christ, to the background. It is important to shift, from retributive justice, to forgiving-love, healing, and reconciliation.

Thus, the theology of forgiving-love forms the basis for interpreting PST within the COCIN, as expression of a life-giving response to the perpetrators of religious violence in Jos (Bevans 2015:195) Reconceptualisation through the Pyem's symbolic religio-cultural experience, seeks to project forgiving-love as the key asset of PST against retributive behaviour by Christians. The Pyem religio-cultural experience also makes dialogue an inescapable and non-negotiable element of forgiving-love theology (Antonio 2006) Dialogue constitutes the process of God's plan to reconcile fallen humanity. The atoning work of Jesus is an expression of God's dialogical love for the fallen humanity. According to Emmanuel Katongole (2009), the dialogue between God and the fallen humanity is expressed fully in the incarnation of Christ. He contends that the missional identity of the church should respond to violence by resisting all forms of retaliation or revenge within the context of religious, tribal and ethnic violence. He emphasises that God's dialogue with the fallen humanity is expressed in the incarnation of Jesus, through the biblical narrative 'Word made flesh and dwelt among us' (John 1:14). Katongole interprets 'Word' as God's gift, which can be accessed by remembering God's act of love and reconciliation (Weaver 2013). 'Made flesh' is interpreted as God identifying with the human context, and 'dwelt among us' is God's practical dialogue with the human context (Katongole 2009:7-8).

This concept offers a theological perspective that uses a practical and contextual dialogue for love and forgiveness. The Pyem notion of ngwakin darsai daal is dialogical. This is expressed in the Pyem response to violent conflict between two communities. Findings from the group discussions of members of indigenous groups revealed that the meeting of the two conflicting communities initiated by Bate $\mathrm{Ya}$ (middlepersons) is believed to be 'a dialogue 
of the equals' (Bida 16 November 2017). Members of the two warring communities are guilty of undermining love for human dignity, and both victims and perpetrators are called to forgive, based on human consciousness, and irrespective of possible damage caused by the violent conflict. Dialogue is expressed, furthermore, at the meeting of the two warring communities, which involves an exchange of male goats and eating male goat meat (Kallamu 16 November 2017). The Pyem notion can be an African symbolic medium, which expresses God's dialogue with the fallen humanity through PST. Unlike the Eurocentric and triumphalist dialogue of PST, which postures with a tendency to discriminate based on religious and cultural affiliation, the concept of dialogue within the Pyem milieu embodies forgiving-love and inclusivity. The dialogical nuance, as perceived, presupposes that God's forgiving-love informs divine dialogues with humanity through Jesus Christ (Buthelli 2015:782-783; Pederson,McKee, Berndt, DePerno\&Wehde 2015:173). Thus, the Pyem notion provides a distinctive option, which advances a life-giving dialogical dimension to understanding and applying the atoning work of Christ within a context plagued by religious violence, such as Jos. In the light of Jesus's teaching, forgiving-love is seen as the voluntary act of responding to harm done to Christians without retaliation (Ezigbo 2018:251-252).

Forgiving-love is expressed through the dialogical exchange of male goats and the communal eating of the goat meat as gesture of negating violence and embracing reconciliation. The act of eating the goat meat is based on the belief that all the grievances, hatred, anger, and un-forgiveness as a result of a fight, are ingested and put to rest. Forgiveness and reconciliation are demonstrated by members of the community through social interactions (Bida 16 November 2017). In general terms, forgiving-love becomes necessary because all who participated in the fight are guilty of undermining the dignity of humanity, which is the bedrock of the life in the community (Bujo 2015:81). The Pyem notion considers every member of the community guilty for failing totake the responsibility to sustain and protect human dignity. The Pyem notion, therefore, has potential to promote forgiving-love as a response to religious violence (Belousek 2011:50). The authenticity of Pyem forgivinglove and reconciliation within their belief system is demonstrated in the value they assign to human dignity and the promotion of inclusive justice for all. Based on this analysis, the Pyem notion becomes a viable symbol, through which PST can be expressed by the COCIN in its response to religious violence in Jos. 


\section{Conclusion}

The ongoing discourse that seeks to unearth Eurocentric Christian doctrines in Africa cannot be underestimated. This is because the de-colonial perspective used for introducing theology in Africa is aimed at stimulating African theologians to utilise their rich, relevant African religio-cultural experiences as symbolic mediums for expressing Western Christian doctrines in the missional identity of the church in Africa, which, in turn, can foster practical Christian living in the context of religious violence in Africa. Following from the Pyem African cultural experience, as described in this article, it is evident that there are relevant alternative models in Africa that can be used to decolonise European-informed Christian doctrines, such as PST, which tends to misrepresent God's broader perspective of mission, especially in a religiopluralistic context, such as Nigeria.

\section{References}

\section{Primary Sources}

Kallamu, Samuel. 16 November 2017. Tongzong, Jos, Nigeria.

Bida, Audu. 16 November 2017. Tongzong, Jos, Nigeria.

Moko, Toni. 16 November 2017. Tongzong, Jos, Nigeria.

Abuku, Bukar. 16 November 2017. Tongzong, Jos, Nigeria.

Suna, Chanwat. 16 November 2017. Tongzong, Jos, Nigeria.

Tafida, Lory. 16 November 2017. Tongzong, Jos, Nigeria.

Mary, Sokale. 16 November 2017. Tongzong, Jos, Nigeria.

\section{Secondary Sources}

Antonio, E. P. 2006. Inculturation and Post-colonial Discourse in African Theology. New York, NY: Peter Lang.

Bartlett, A.W. 2001. Cross Purposes: The Violent Grammar of Christian Atonement. Harrisburg, PA: Trinity Press International.

Bate, S.C. 2000. Human is Cultural: Introducing Anthropology. Pietermaritzburg: Cluster Publications.

Belousek, D. 2011. Nonviolent God: Critical Analysis of a Contemporary Argument. Conrad Grebel Review 29: 49 - 70.

Bevans, S. 2015. Life, Joy and Love: Together towards Life in Dialogue with Evangelii Gaudium and The Cape Town Commitment. International 
Yusuf J. Luxman, Chammah J. Kaunda \& Roderick R. Hewitt

Review of Mission 104,2: 193 - 202. https://doi.org/10.1111/irom.12095

Boer, J.H. 2014. The Last of the Livingstones: H. Karl W. Kumm's Missiological Conception of Civilization. Unpublished MTh dissertation.

Faculty of Theology, Free Reformed University of Amsterdam.

Bujo, B. 2015. Distinctive African Ethics. In Stinton, D.B. (ed.): African Theology on the Way: Current Conversations. London: SPCK.

Bultmann, R. 1985. aphiemi, aphesis, paresis. Theological Dictionary of the

New Testament. In Kittel, G. \& Gerhard Friedrich (eds.). Grand Rapids: Eerdmans.

Buthelli, F.G. 2015. Citizenship and Public Theology: A Lutheran Approach from Brazil. In Sinnetal, S. (ed.): Religious Plurality and the Public Space: Joint Christian - Muslim Theological Reflection. Geneva: Lutheran World Federation.

Ezigbo, V.I. 2018. Violent Christians, the Nigerian Public Square, and the

Utility of Jesus' Sayings for Tackling Religious Violence. International

Journal of Public Theology 12, 2: 236 - 259.

https://doi.org/10.1163/15697320-12341537

Goshit, Z., P. Lere, B. Tang, J. Longkat, \& N. Gutip (eds.). 2013. Profile and Composition of the Ten Provincial Councils (PCCs). In Goshit, Z. (ed.): History of the Church of Christ in Nations (COCIN) 1904-2013. Jos: Hamtul.

Green, J.B. \& M.D. Baker 2000. Recovering the Scandal of the Cross: Atonement in New Testament and Contemporary Context. Carlisle: Paternoster.

Grudem, W. 1994. Systematic Theology: An Introduction of Biblical Doctrines. Grand Rapids, MI: Zondervan.

Hegel, C. 2001. The Philosophy of History Georg Wilhelm Hegel. Kitchener: Batoche.

Higazi, A. 2011. The Jos Crisis: A Recurrent Nigerian Tragedy. Discussion

Paper 2, Janaury: Friedrich Ebert Stiftung. Available at: https://library.fes.de/pdf-files/bueros/nigeria/07812.pdf (Accessed on 11 September 2019.)

Kant, I. 1960. Observations on the Feeling of the Beautiful and Sublime.

Goldthwaite J.T. (trans.). London: University of California Press.

Kaunda, C.J., Y.J. Luxman \& R.R. Hewitt 2018. 'The Male-Goat that Stops Fighting': The Pyem Philosophy of Reconciliation and Conflict Resolution. Pharos Journal of Theology 99. Available at: 
https://www.pharosjot.com/uploads/7/1/6/3/7163688/article 9 vol 992 018_chammah_ukzn.pdf (Accessed on 10 September 2019.)

Kaunda, C.J. 2015.The Denial of African Agency: A Decolonial Theological Turn. Black Theology: An International Journal 13, 1: 1 - 23.

https://doi.org/10.1179/1476994815Z.00000000048

Kaunda, C.J. 2016.Towards an African Eco-gender Theology: A Decolonial Theological Perspective. Stellenbosch Theological Journal 2, 1: 177 202. https://doi.org/10.17570/stj.2016.v2n1.a09

Katongole, E. 2009. Identity, Community and the Gospel of Reconciliation:

Christian Resources in the Face of Tribalism. The Great Lakes Initiative Duke Centre for Reconciliation. Available at:

https://www.goodreads.com/

(Accessed on 22 August 2017.)

Krause, J. 2011. A Deadly Cycle: Ethno-religious Conflict in Jos, Plateau State, Nigeria. Geneva: Geneva Declaration Secretariat.

Kumm, H.W. 1907. The Sudan: A Short Compendium of the Facts and Figures about the Land of Darkness. London: Marshall Brothers.

Lenman, B. \& G. Parker 1979. The State, the Community and Criminal Law in Early Modern Europe. In Gattrell, V.A.C. (ed.): Crime and the Law: The Social History of Crime in Western Europe Since 1500. London: Europa Publications, pp.11-48.

Machunga, A. 1962. Pyem- Gindiri Tarihi. Jos: Gindiri Press.

Mignolo, W.D. 2007. Introduction: Coloniality of Power and De-colonial Thinking. Cultural Studies 21, 2-3: 155 - 167.

https://doi.org/10.1080/09502380601162498

Nden, S. 2013. The Formation of the SUM and CUMP. In Goshit, Z. (ed.): History of the Church of Christ in Nations (COCIN) 1904-2013. Jos: Hamtul.

Njoku, F. 2009. Igbo Philosophy: An African Perspective on the Problem of Identity and Conflict Resolution. New Jersey: Golden \& Jacob Publishers. Pederson, A.M., G.S. McKee, E. Berndt, M. DePerno \& E. Wehde 2015. Fully Human and Fully Divine: The Birth of Christ and the Role of Mary. Religion 3:172 - 181. https://doi.org/10.3390/rel6010172

Pugh, B. 2015. Atonement Theories: A Way through the Maze. Cambridge: James Clark. https://doi.org/10.2307/j.ctt1cgf45k

Pokol, B.J. 2015. Peacebuilding in Nigeria: A Missio-Political Critique of the Church of Christ in Nations' Relationship with Plateau State within the 
Yusuf J. Luxman, Chammah J. Kaunda \& Roderick R. Hewitt

Context of Violent Conflict in Jos, Nigeria (2001-2010). Unpublished PhD Thesis, University of KwaZulu-Natal, Pietermaritzburg.

Pokol, B.J. \& C.J. Kaunda 2015. Integrating Suum-ngi Theology of Peace in

Gindiri Theological Seminary Curriculum in Nigeria: An African

Perspective. Missionalia 43, 2: 232 - 247. https://doi.org/10.7832/43-2-

$\underline{102}$

Rengshwat, J. 2012. The United Mission British Branch 1934-1977: An Examination of the Mission's Indigenous Church Policy. Unpublished

PhD Thesis, University of Jos, Nigeria.

Rodríguez Maeso, S. \& M. Araújo 2017. The (Im)plausibility of Racism in

Europe: Policy Frameworks on Discrimination and Integration. Patterns of Prejudice 51, 1: 26 - 50.

https://doi.org/10.1080/0031322X.2016.1270500

Serequeberhan, T. 1997. The Critique of Eurocentrism and Practice of African

Philosophy. In Eze, E. (ed.): Philosophy from African Philosophy: A

Critical Reader. Oxford: Blackwell Publishing.

Taylor, M. 2006. The Atonement Debates with Contemporary Evangelicalism

1 - 20. Available at: https://thinktheology.co.uk/pdf/Atonement (Mick

Taylor).pdf/ (Accessed on 11 June 2018.)

Temple, C.L. 1965. Notes on the Tribes, Provinces, Emirates and States of the

Northern Provinces of Nigeria. Temple, O.S.M.M. (comp. \& ed.).

Available at: https://catalog.hathitrust.org/Record/012308939

Tutu, D.M. 1999. No Future without Forgiveness. London: Rider.

https://doi.org/10.1111/j.1540-5842.1999.tb00012.x

Ukpong, J. 2000.Developments in Biblical Interpretation in Africa. Journal of

Theology for Southern Africa 108: 1 - 18.

Uzodike, N. \& T. Obaje 2013. The Question of Youth Participation in

Peacebuilding Processes in Jos, Plateau State, Nigeria. Accord

Conference Paper. African Centre for the Constructive Resolution of

Disputes.

Vanhoozer, K.J. 2004.The Atonement in Postmodernity: Guilt, Goats and

Gifts. In Hill, C.E. \& F.A. James (eds.): Glory of the Atonement: Biblical

Historical and Practical Perspectives. Downers Grove, IL: InterVarsity Press.

Weaver, J.D. 2013. The Nonviolent God. Grand Rapids, MI: Eerdmans.

Wika, P.N. 2014. Unveiling the Silent Issues in the Protracted Jos Crises,

Central Nigeria. Modern Africa: Politics, History and Society 2. 
A Theology of Forgiving-Love

Yusuf J. Luxman (PhD)

PhD Graduate

Systematic Theology

University of KwaZulu-Natal

South Africa

luxmanyusuf@yahoo.com

Chammah J. Kaunda (PhD)

United Graduate School of Theology

Yonsei University

Korean Republic

pastorchammah@gmail.com

Roderick Hewitt $(\mathrm{PhD})$

School of Religion Philosophy and Classics

University of Kwa Zulu Natal

South Africa and

Visiting Fellow at New College

University of Edinburgh, Scotland

hewitt@ukzn.ac.za 